\title{
The Brazilian Wine Industry: a case study on geographical proximity and innovation dynamics
}

\author{
Claudio Vinicius Silva Farias ${ }^{1}$ and Ana Lúcia Tatsch ${ }^{2}$
}

\begin{abstract}
This paper aims to analyze the cooperation and learning processes in the local system of vitiviniculture production of Serra Gaúcha's region (Rio Grande do Sul, Brazil), in order to characterize the dynamics of innovation of the firms located there. In methodological terms, a non-probabilistic exploratory study has been conducted. Field research in 20 wineries as well as interviews with related organizations were carried out in order to understand which learning mechanisms support innovative strategies adopted by enterprises. Since learning processes are also the result of local interactions, it was necessary to understand whether these interactions produced cooperative links. The results showed that innovations made by the firms were basically incremental. To do so, they use their intrinsic learning processes as well as external agents. These agents can be located in the region or elsewhere. The geographical proximity becomes more relevant for smaller firms. It was still possible to perceive the existence of cooperation in both vertical and horizontal level. Most frequent actions of vertical cooperation occur especially between firms and their suppliers. When horizontal cooperation occurs between enterprises, it takes place particularly in international trading.
\end{abstract}

Key-words: learning, innovation, cooperation, local production systems, clusters, vitiviniculture.

Resumo: Esse trabalho visou analisar os processos de cooperação e aprendizagem no sistema local de produção vitivinícola da Serra Gaúcha (Rio Grande do Sul, Brasil), de modo a caracterizar a dinâmica inovativa das empresas ali localizadas. Em termos metodológicos, foi feito um estudo exploratório não probabilístico. Foram realizadas pesquisa de campo com 20 vinícolas e entrevistas com organizações afins, visando entender que mecanismos de aprendizado dão suporte às estratégias inovadoras adotadas. Uma vez que tais processos ocorrem sob a forma de relacionamentos intrínsecos à localidade, pretendeu-se compreender

1. Professor do IFRS - Campus Porto Alegre. Doutorando em Desenvolvimento Rural (PGDR/ UFRGS). E-mail: claudio.farias@poa.ifrs.edu.br

2. Professora do Departamento de Economia e Relações Internacionais e do Programa de Pós-graduação em Economia da Universidade Federal do Rio Grande do Sul (UFRGS). Email: analuciatatsch@gmail.com 
se tal interação possibilitava o estabelecimento de vínculos cooperativos. Dentre os resultados, verificou-se que as empresas inovam basicamente de forma incremental. Para tanto, se valem especialmente dos processos de aprendizado intrínsecos, mas também da interação com agentes externos. Esses agentes podem estar localizados na região ou fora dela. A proximidade geográfica torna-se mais relevante para as firmas de menor porte. Foi ainda possível perceber a existência de cooperação tanto em nível vertical quanto horizontal. As ações de cooperação vertical mais frequentes ocorrem especialmente entre empresas e seus fornecedores. Quando ocorre a cooperação horizontal entre as empresas, se dá particularmente na esfera da comercialização de produtos no exterior.

Palavras-chaves: aprendizado, inovação, cooperação, sistemas locais de produção, aglomerados produtivos, vitivinicultura.

JEL Classification: L200, L660, O120, O390, O430.

\section{Introduction}

This article describes the results of a study aimed at analyzing the processes of learning and cooperation that characterize the innovative dynamics of Brazilian wineries. The study is based on the neo-Schumpeterian framework. The authors of this current point out that innovation is systemic, i.e., firms do not innovate singly but try to interact with other organizations, such as universities, research centers or other firms. This interaction leads to the construction of several different learning processes that may occur in the repeated execution of activities, the use of equipment, and mainly the interaction between economic agents.

Such processes are also influenced by the local characteristics of the firms, such as social, institutional and productive structures of each region. Maskell and Malmberg (1999) point out that firms build their competitiveness in an interactive way, based on local qualification, once they make use of local infrastructure and institutions. These capabilities are shaped by historical, social, geographical and economical aspects, turning each region or space into a unique locus for interaction and collective learning, having different impacts on the agents located there. Therefore, the space or territory must be seen as an important element for the analysis of innovation and learning processes, once the geographical proximity will favor interactions and, consequently, innovation and learning $^{3}$ (CASSIOLATO and LASTRES, 1999).

Regarding the Brazilian vitiviniculture state, around $90 \%$ of the national production is actually concentrated in Rio Grande do Sul State, mainly in the Serra Gaúcha's region (MELLO, 2013), which presents particular local system and representativeness characteristics. As main features, it is worth mentioning the productive specialization and the significant presence of geographically concentrated enterprises in the production of wine and derivatives as well as other related segments, such as equipment producers. This structure is supported by a set of public and private institutions that play different and complementary roles ranging from support to research and technological innovation to the formation of qualified labor, as well as the political and social consolidation of Brazil's wine industry.

Based on these statements, this study was proposed in order to provide new evidence on the "territorial approach"4, which bases its analysis on the dynamic interaction of economic and institutional actors in certain spaces. The research

3. This approach of geographic proximity of firms has its crib set up in Marshall, who emphasizes the existence of "positive externalities" inherent in the agglomeration of firms.

4. See, for example, Becattini (1990), Cassiolato and Lastres (2003), Courlet (2001), Markusen (1995), Schmitz (1995) e Storper (1997). 
was conducted in twenty wineries with different sizes, all located in a contiguous geographic region called "Serra Gaúcha", in Rio Grande do Sul State, in southern Brazil. The research also included interviews with related organizations to better understand which learning mechanisms support the innovative strategies adopted by the enterprises. Since learning processes are also the result of local interactions ${ }^{5}$, it was necessary to understand whether these interactions produced cooperative links, specifying them.

\section{Theoretical foundation}

\subsection{Learning}

For neo-schumpeterian authors, the learning processes do not take place only in formal education. For these authors, learning is closely related to the ability to produce knowledge. This knowledge is structured through a learning comprised of "[...] several different processes that lap over and feed each other back" (ROSENBERG, 2006, p. 108). In other words, the performance of agents and institutions depends directly on learning.

Bessant et al. (1999) suggest that three main elements compose the learning process: a) accumulation and development of "central competencies", which make firms different from each other, giving them competitive advantage potential or not; $b$ ) temporal dimension - learning (as a continuous and cumulative process) involves a long-term process; c) "the idiosyncratic component" - learning processes are part of the organizations and their settings, and can hardly be replicated by others.

There are several forms of learning linked to the different ways to spread and acquire knowledge. These processes might be associated with the knowledge accumulated in production

5. The local environment must not be seen as a unit closed in itself, once its different actors - firms and several other organizations - establish important relationships with other agents not located there (TATSCH, 2008, p. 68). activities, known as learning-by-doing (ARROW, 1962). On the other hand, learning might result from the use of a certain good or service, known as learning-by-using (ROSENBERG, 2006). However, perhaps the most important learning way among firms regards on interaction with other agents (such as suppliers and agents), known as learning-by-interacting (LUNDVALL, 1988). Thus, innovation processes and production activities require specific forms of interaction between economic agents, even as between economic agents and institutions.

This emphasis on interaction corresponds to the conditions and settings in which firms are inserted, facilitated by the proximity among agents. According to Malmberg and Maskel (2006), the proximity in "local learning" has spatial dimensions that can be verified vertically (in learning-by-interacting, due to the relationship between companies in different links in the chain), horizontally (in learning-by-monitoring, which privileges observation and comparison among firms) and socially, by common habits and values (resulting from social capital accumulated in the interaction space among agents).

Learning processes are multiple, but in the specific case of firms located in local production systems, learning through interaction plays a relevant role. Johnson and Lundvall (1994) formulate some hypotheses about the setting where the learning process by interaction takes place, which can be correlated with the setting where these local systems are formed. Firstly, this type of learning involves a "social process" that requires the agents' own language, through codes and channels of communication among them, in order to enable the exchange of information. Secondly, the more complex learning is, the more need for interaction to make it feasible.

Interaction learning many times requires non-economic relationships among the agents, through which reciprocal trust principles may be gradually consolidated (PUTNAM, 1996; COLEMAN, 1985). Finally, learning by interaction required some time to develop, not only due to the need for consolidating this reciprocal trust 
among agents, but also for the investments required. For this reason, it is important to understand these interactive processes in specific social, economical, and cultural settings.

In summary, learning is related to a cumulative process in which firms broaden their knowledge, enhance their search procedures and refine their ability to develop and manufacture products. According to Dodgson (1996, p. 55), "learning can be described as how firms build and organize knowledge and routines around their competencies and culture and how to adapt and develop organizational efficiency through improving the use of these competencies." Therefore, learning continuously broadens the firm's knowledge, enabling them to incorporate innovations, as well as new productive and technological opportunities, leading to the expansion to new markets.

\subsection{Innovative Processes}

The innovative process is a result of learning processes. According to neo-schumpeterian thoughts, innovation must be understood as a result of this interactive learning process between firms and their environments. Thus, the environment in which agents are involved, together with their cultural, socioeconomic and political characteristics, interferes and influences the way knowledge is produced and circulate among the different actors. Likewise, the possibility of knowledge exchange is enhanced and stimulated by the physical proximity of the agents.

Innovation plays a key role among the main neo-schumpeterian authors. This approach has the following theoretical axes (NELSON and WINTER, 1982; DOSI, 1982 and 1988): (i) behavioral diversity among agents, endogenously produced by the search for innovation opportunities; (ii) selecting companies, strategies and/or technologies through dynamics based on competition and continuous change. Two concepts are perceived: companies' search for introducing innovations (according to Schumpeter, incorporating new products, production methods and new markets) that allow them to obtain competitive advantage (DOSI, 1988), and selecting these innovations in the economic setting.

Following Schumpeter's tradition, the analysis developed by the neo-schumpeterian current is not based on balance assumptions (despite "dynamic"), but on "imbalance", intrinsic to the capitalist economy once it is generated by the quest for higher profitability opportunities among the firms, usually represented by innovations that, in turn, initiate cumulative dynamic effects of lack of adjustment and expansion.

In contrast with the assumptions adopted in the neoclassical theory, neo-schumpeterian models take imbalance as a norm and adopt a disaggregated analysis (sector, industrial and technological) focused on the asymmetries of the competition processes and technical, economic and strategic diversity that originates the evolutionary dynamics and the structural change of capitalist economies (POSSAS, 1996).

Therefore, innovation processes and learning are perceived as intrinsically linked, once these processes are inserted in an institutional environment that stimulates innovation and interaction and cooperation processes among organizations. This is more evident in local production systems due to their institutional construction, once they are formed by the culture and social relationship geographically located.

To Vargas (2002), the interactive nature of the learning process appropriately introduces geographical space as a dimension of analysis. As local environment is conceived as a set of institutional and organizational configurations inserted in a series of interactions with different economic agents, the located dimension of learning processes as well as firms' innovation is considered relevant. 
Figure 1. Firms interviewed by Municipalities

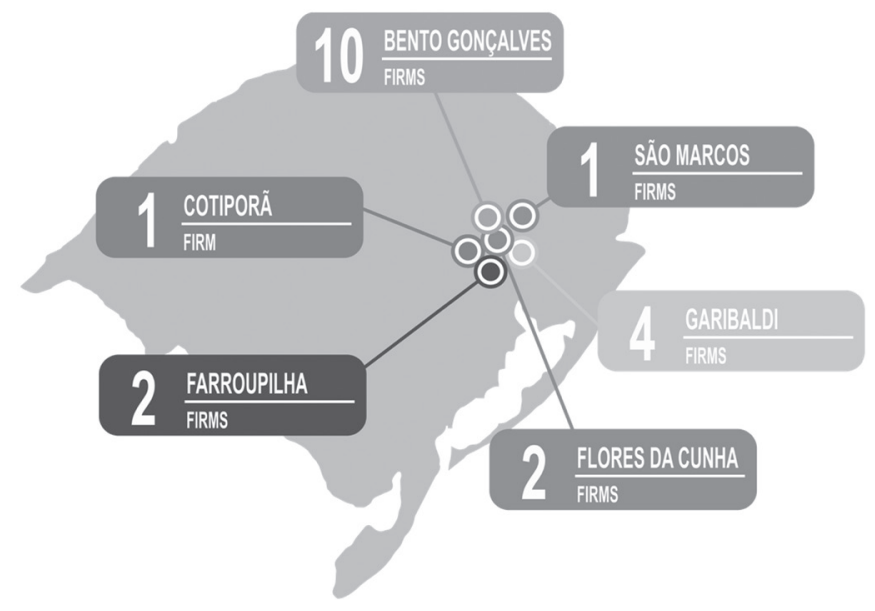

Source: Research Data

\section{Methodological procedures}

This exploratory study used the nonprobability sampling method, using structured questionnaires. Previous interviews were carried out from August to October 2009, with winemakers, researchers, representatives of educational institutions, and support organizations. After this phase, these respondents were asked to indicate which enterprises could be considered representative of Serra Gaúcha's wine cluster. The firms mentioned were contacted in order to check their availability to join the study.

The survey was applied to twenty wineries belonging to the local system studied, during January and February 2010. It is important to highlight that these wineries accounted for $21 \%$ of the total wine production in Rio Grande do Sul State in $2009^{6}$. This non-probability sampling was significantly representative, even representing the reality of Brazilian producers. Figure 1 shows the location of the wineries included in this study. The map highlights the number of

6. The twenty companies total a production of about $70.5 \mathrm{~m}$ liters of wine in 2009. Data from IBRAVIN during interviews, pointed that the production of wineries was $342 \mathrm{~m}$ liters in the same year. firms interviewed in each municipality of Serra Gaucha's region.

The data collection instrument was a survey consisting of 48 questions, grouped into five sections: I) identification of the company; II) production, markets and employment; III) innovation, cooperation and learning; IV) structure, governance and benefits associated with local environment; and V) promotional activities. Data analysis was performed based on the frequency distribution of responses. The questionnaires were applied in person directly to the director, manager or enologist in each winery. The information collected in the direct investigation was examined in terms of content analysis and descriptive statistics.

Another important characteristic of the sample was the segmentation by size. Due to a peculiarity in the wine production, the usual classification of companies that considers the number of employees is inappropriate. In general, quality wines require more labor than table wines. Therefore, the size of the companies was determined based on their revenues. Based on the information provided by the companies, their revenues were estimated and later segmented into the company classification used by the Brazilian institution Banco Nacional de 
Table 1. Distribution of Municipalities versus sample firms (by size)

\begin{tabular}{lcccc}
\hline \multirow{2}{*}{ Municipalities } & \multicolumn{3}{c}{ Size } & \multirow{2}{*}{ Total } \\
\cline { 2 - 4 } & micro & small & medium & \\
\hline Bento Gonçalves & 4 & 4 & 2 & 10 \\
Cotiporã & 0 & 1 & 0 & 1 \\
Farroupilha & 1 & 1 & 0 & 2 \\
Flores da Cunha & 1 & 1 & 0 & 2 \\
Garibaldi & 4 & 0 & 0 & 4 \\
São Marcos & 0 & 1 & 0 & 1 \\
Total & 10 & 8 & 2 & 20 \\
Total & 10 & 8 & 2 & 20 \\
\hline
\end{tabular}

Source: Research data.

Figure 2. Distribution of sample firms by founding period

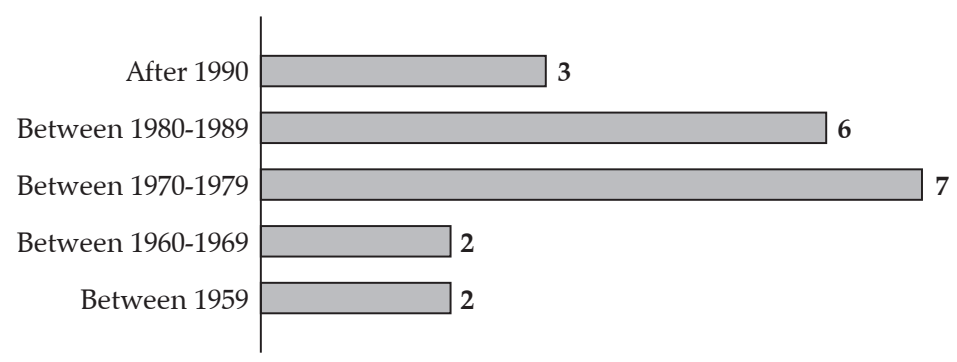

Source: Research data.

Desenvolvimento Social (BNDES)7. Although this method was a strategy of researchers towards respondents' unwillingness to provide data on their revenues (real data are approximate), $90 \%$ of the enterprises interviewed are classified as micro and small firms.

\section{Results and Discussion}

\subsection{General characteristics of the firms surveyed}

All companies investigated are national and independent. As far as location is concerned (Table 1), most companies were within Bento Gonçalves municipality (50\%), followed by Garibaldi (20\%),

7. BNDES establishes the size of companies according to revenues per year: Microcompany (up to $\mathrm{R} \$ 2,400,000.00$ ); Small company (from R $2,400,000.00$ to $\mathrm{R} \$ 10,500,000.00$; Medium-sized company (from R\$ 10,500,000.00 to $\mathrm{R} \$ 60,000,000.00$ ) and Large company (above R\$ $60,000,000.00)$.
Farroupilha (10\%), and Flores da Cunha (10\%). Two companies are located in Cotiporã and São Marcos counties. This distribution is easily explained by the predominance of production and the number of firms in Bento Gonçalves and Garibaldi, respectively the major still wine and sparkling wine producers in Brazil (FARIAS; CAMPREGHER, 2008).

The firms interviewed have an average of 19 employees, including winery and countryside ones. Concerning the latter ones, there is a significant amount of seasonal workers, especially during vintage. Only one company claimed to have only five employees and two companies claimed to have over a hundred employees (one of them has over 400 direct employees). The number of employees is directly related to the company's productive option, i.e., focusing on quality wines demands more labor than table wines.

Considering the sample's distribution by foundation period (Figure 2), we found that the majority of companies $(65 \%)$ started their activities 
between the 70's and the 80 's, while $10 \%$ began operating before 1959, and 10\% in the 1960's. Only 15\% started their operation after 1990.

The fact that $65 \%$ of the companies came up during the 70 's and 80 's confirms the assumption that, in this period, there was intense movement towards expanding the professionalization and industrialization of national wine. Both decades were marked, respectively, by moments of great opportunities for companies in this sector. Firstly due to increased purchasing power of the named middle class, and afterwards by stability and increasing affluence of lower classes. The wineries founded in this last period invested on diversification, especially including quality wines in their production line. It is, therefore, the increase in purchasing power and the domestic market dimension that foster the emergence of higher quality wines (VARGAS, 2002).

The companies emerging after the 70's present a different characteristic, once they work with premium and sparkling wines. Five companies interviewed started their activities during the 90's, after the implementation of the Real currency. These firms have been specializing in high quality wines, attempting to control the quantity produced as a way to ensure an exclusive goods and therefore, take full advantage of the wine consumption development, even if it represents an expansion of foreign product consumption in Brazil.

Most of the enterprises have adopted premium wine production as a market strategy (only one claimed not to work with premium wines), either for permanence or expansion, whereas $63 \%$ of them have been working with premium wines for less than 10 years. This data supports the evidence that companies have been making efforts in order to increase production, particularly with quality wines, as well as to include geographical and protected designation of origin on their label.

Regarding sale strategies, $65 \%$ of the companies considered custom orders highly important, due to the fact that several of them work with premium wines, using that as the main way of distribution.
Similarly, $56 \%$ of the companies claimed that it is highly important for productive units to have their own stores. This strategy is generally adopted by companies focusing on visibility at a low cost, offering variety and competitive price of goods.

When asked about the importance of retailers, especially supermarkets, as a wine distribution channel, there was no consensus among the respondents. For $35 \%$ of the companies in the sample, supermarkets are not the preferred channel, while $53 \%$ claimed that this is the main point of sales. This information shows the high level of suspicion between wineries and retailers. According to a study conducted by IBRAVIN in 2009, about $70 \%$ of all wine sold in Brazil (domestic and imported) takes place in supermarket aisles (IBRAVIN, 2010). It is no wonder why $82 \%$ of respondents attribute high importance to sales through distributors and representatives who usually work in their local or regional markets via smaller-sized retailers, once it enables them to widen the winery's scope of action, as well as expand gains and bargaining power towards retail chains.

Considering the great diversity on product lines, it was extremely difficult for companies to present precise estimates related to their sales between 2007 and 2009. Hence, these figures account for the average of estimates made by the companies in an overall view. Therefore, the companies investigated concentrate $15 \%$ of their sales in the surroundings, $20 \%$ for other towns, $63 \%$ for other Brazilian states and only $2 \%$ export.

According to that previous characterization, it is possible to present the following opinion regarding innovation, cooperation and learning process.

\subsection{Innovation}

All companies informed to have introduced some sort of innovation (on product, process or organization) $)^{8}$ during the analyzed period (2007 - 2009). Despite showing high rate of innovation

8. The same definition from the Pesquisa Industrial de Inovação Tecnológica - Pintec (IBGE, 2010) was used. 
when compared to the average domestic industry ${ }^{9}$, one may note that none of the companies has introduced any unprecedented innovation in the sector. The innovations implemented were all enhancement ones, largely reproducing improvements (on products and processes) carried out by leading companies in local and international markets.

Enquired about which agent played the most important role in the development of product innovation, $95 \%$ of the companies informed they were the authors of the innovation. Only one company claimed to have developed such innovation in cooperation with other companies and institutes. Most companies presented the introduction of a new label or a premium wine as product innovation. Many companies also informed they invested in the development of sparkling wines, and this is the specific case where cooperation activities arise for the development of the product. This is due to the fact that manufacturing a good sparkling wine requires high quality "base wine". However, many companies, especially micro and small ones, either do not own the "base wine" or the necessary equipment for manufacturing sparkling wine. This implies in the shared use of equipment, like cooling tanks, which, due to its elevated cost, are not yet popular, among micro and small firms.

According to data provided by IBRAVIN (personal communication), one of the most significant product innovations in the last years was the improvement and expansion of the production of grape juice in its several forms (concentrated, sweetened, organic, etc.). This organization registered a growth up to $40 \%$ on grape juice production in the last two years. Grape juice has also brought about a significant level of cooperation among companies, once many of them do not own specific equipment.

When asked about the authorship of the main innovation process, $75 \%$ of the investigated

9. According to PINTEC (IBGE, 2010), about 38\% of the Brazilian industrial companies are considered innovative. companies claimed to have developed the innovations themselves. On the other hand, $25 \%$ informed that, in the last three years, they have received support of other companies or institutions for the development of innovative processes. It is important to highlight that, as it occurred with product innovation, innovations introduced by the firms were mainly on improvement action, rather than new processes.

In the last years, innovations on grape production process have reached wineries more quickly, partly due to the market pressure in order to obtain a better quality product, as well as the fact that several wineries and organizations are involved in geographical indications, which reinforces the need for obtaining better quality inputs (MELLO, 2013).

Another process innovation in the grape production step consists of enhancing the vine reconversion, i.e., the replacement of vineyard, driving trellising systems from pergola to vertical-shoot-positioned (VSP), in order to obtain average productivity between 7 and 10 tons per hectare. In Serra Gaúcha, the number of grapes destined to the production of quality wines, such as Cabernet Sauvignon, Merlot and Tannat, has been expanding. These grape plant varieties are mostly imported from Italy and France, although they are endogenously developed, produced and sold by the government enterprise, Empresa Brasileira de Pesquisa Agropecuária (Embrapa).

The first great innovation introduced by the companies in the winemaking process regards the mechanization of different processes. Investments for acquisition of treadmills for the reception of grapes and destalkers comprise the main process innovations, once they allow for destalking and the first steps of fermentation and maceration. For $45 \%$ of the companies in the sample, this equipment was imported, but could have been acquired in the national market through manufacturing companies located in São Paulo. Two micro firms in the sample claimed to have imported or bought second-hand equipment from other wineries in the region. 
Although the cluster already develops a small local industry of machinery and equipment, for some product either there is no national counterpart, or the existing ones do not meet the quality standards required by the wineries, which are established by great international players (equipment manufacturers).

Finally, the last innovation most frequently mentioned by the companies and organizations is related to wine storage and ageing. Ageing in wooden barrels is the last innovation process and it is directly related to added value to the product.

The Table 2 bellow summarizes all this information.

Organizational changes were present in the routine of $65 \%$ of the firms interviewed. Among the main changes, there is the implementation of the structural organization of firms, followed by alterations in marketing and sales concepts and practices. Only three companies claimed to have started changes in management processes in order to meet certification norms, such as ISO 9000.

Among organizational changes, there was the introduction of regular performance assessment meetings, and the implementation of career and salary programs. For almost all companies, the main partner in those organizational changes has been the Brazilian institution, Serviço Brasileiro de Apoio às Micro e Pequenas Empresas (SEBRAE), which provides technical and training support for these cases.

The importance of the impact of product and process innovation on the enterprises' overall performance was also identified. Figure 3 lists these impacts from the perception of respondents. They claimed that the most important innovation was the diversification of products, as a deliberate strategy to ensure maintenance and expansion of markets. For $94 \%$ of the sample, product and process innovation raised product quality, keeping their market share. For $88 \%$ of the respondents, those innovations were important to increase productivity, allowing supply expansion in the domestic market, as well as opening new ones. For $76 \%$ of the companies, the use of those innovations, associated with organizational innovations, reduced the environmental impact. In $65 \%$ of the cases, the implementation of these innovations enabled the company's participation in the foreign market. Similarly, these innovations were important to fit the firms into regulations and norms related to domestic and foreign markets.

From 2007 to 2009, all wineries invested on machinery and equipment purchase, which led to significant technological improvement of products and processes. This corroborates the idea that some of them choose to acquire technologies. This situation is reinforced by the fact that $44.4 \%$ invested on training courses, even the ones used in the vineyard reconversion. The purchase of technology requires investments that go beyond the acquisition value of the machine, but contemplates also the need for training to the workers involved in these novel technologies or processes.

The fact that these enterprises make little investments in research and development (R\&D)

Table 2. Innovations and main agents of development

\begin{tabular}{lll}
\hline & \multicolumn{1}{c}{ Product Innovation } & \multicolumn{1}{c}{ Innovations Process } \\
\hline Self development & Introduction of quality wines & $\begin{array}{l}\text { Soil and Vines* } \\
\text { Conversion of vines }\end{array}$ \\
& & Mechanization of receipt of grapes to fermentation \\
& & Automation of fermentation \\
& & Investment in aging and storage of goods \\
\hline Development with Partners & $\begin{array}{l}\text { Introduction of sparkling } \\
\text { Introduction of grape juice }\end{array}$ & $\begin{array}{l}\text { Soil and vines* } \\
\text { Conversion of vines* }\end{array}$ \\
\hline
\end{tabular}

Note: Innovations indicated with $\left({ }^{*}\right)$ are developed either by enterprises individually, as by those with the help of partners (companies and institutions).

Source: Research data. 
Figure 3. Impact of product and process innovation on the enterprises' performance

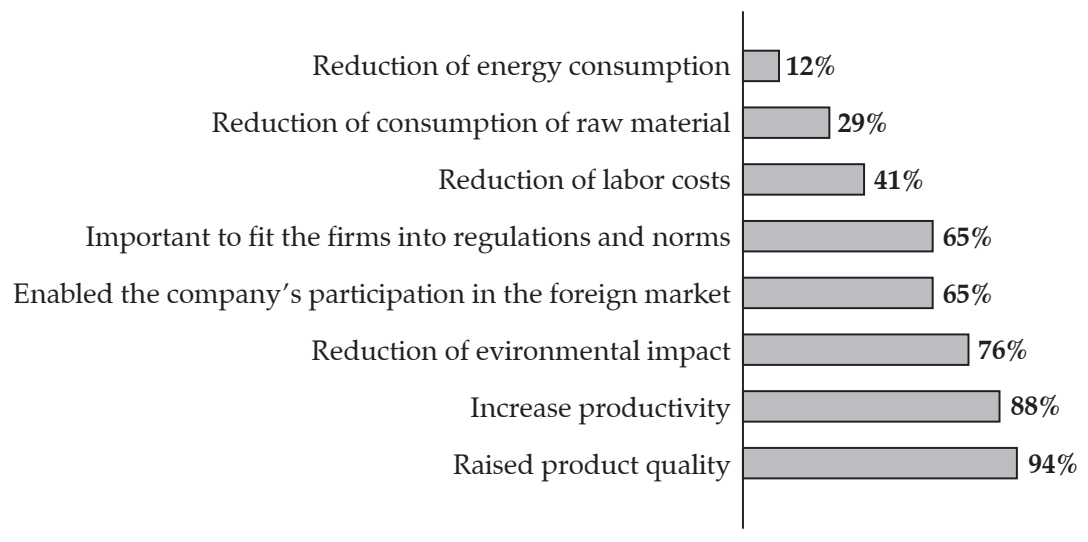

Source: Research data.

suits the sample profile: micro and small firms, manufacturers of traditional products that use mature technologies. In addition, the low use of $R \& D$ relies on the fact that innovations are, in short, enhancement ones, not requiring great technological apparatus related to the productive process. The exception to this are two of the larger companies interviewed, which have their own laboratories with about ten professionals in chemistry, enology, biotechnology and food engineering.

However, R\&D investment lacks do not mean these activities are not developed. In this local system, several organizations present in the cluster play the role of executing and supporting this task, such as Embrapa Uva e Vinho ${ }^{10}$ and the Instituto Federal do Rio Grande do Sul (IFRS) ${ }^{11}$.

10. Embrapa is the research branch of the Ministerio da Agricultura, Pecuária e Abastecimento, with 46 units of service and applied research nationwide and it is definitely one of the institutes responsible for the successful Brazilian performance in the agribusiness. In this scenario, EMBRAPA Uva e Vinho is considered the largest institution for vitiviniculture research in the country. It was founded in 1975, during the third stage of the industrialization of the Brazilian vitiviniculture, characterized by great investments in the modernization of the sector.

11. The current Instituto Federal de Educação, Ciência e Tecnologia do Rio Grande do Sul (IFRS), Bento Gonçalves Campus, in 52 years has always played a key role in the qualification of labor linked to grape growing and wine production in the region. It represents an important center for the development of local, regional and national human resources. The institution was founded in 1959 after Law number
The technological research developed by both institutions is shared with the enterprises in many ways, such as scientific events for enologists, academic and professional programs developed in this educational institution, as well as extension programs. Still, there is little interaction between firms and this sort of institution (teaching and research). This information is corroborated by the fact that $25 \%$ of respondents claimed to have developed some innovation with another company or institution during the period analyzed.

\subsection{Learning processes and sources of information}

Another relevant question was whether wineries carried out training and qualification programs to their human resources. This is an important evaluation, once these activities develop formal or informal learning processes within companies as well as the cluster. More than half of respondents (55.6\%) claimed to have carried out internal training courses. Another remarkable characteristic is the preference for local technical schools for training programs (83.3\%), consolidating the importance of the local system for the qualification of local labor.

3646, as the Viticulture and Enology School of Bento Gonçalves and started to operate in 1960. 
In order to analyze learning processes, the flow of information and the use of internal and external sources were identified. Therefore, the research instrument attempted to analyze, during the period evaluated, the degree of importance attributed to internal sources of information (R\&D, production and sales areas, etc.) and external ones (clients, competitors, universities, research centers, etc.).

Technological learning mostly takes place through learning-by-doing, or through hiring technical professionals from the local teaching institutions. There is clear preference for hiring local professionals and a certain degree of rejection to professionals from other regions. Similarly, wineries seem to be the destination for those coming out of local universities (83.3\%), as well as technical schools located in the cluster (77.8\%).

The main source of information for learning comes from within the firms (Figure 4). In this sense, information coming from R\&D, laboratories $(73 \%)$, and production $(75 \%)$ plays a key role. Sales, marketing and customer service also show high importance for learning processes within the firm $(75 \%)$. This situation reinforces that the kind of learning used in wineries is learning-by-doing, once learning is based and derives from these companies' own productive activity.

Regarding to external sources of information (see Figure 5). When asked about the importance of these sources of learning, the wineries interviewed focus on the relationship with research institutes, especially Embrapa (95\%). Embrapa is acknowledged nationwide as well as internationally for its scientific productions in the areas of grape growing and winemaking. On the other hand, only $5 \%$ of the companies in the sample consider universities and technical schools important sources of information on technology and enhancement of production activities.

According to $85 \%$ of the sample, external sources of information hold a high level of importance, such as machinery, equipment and input suppliers (chemical and enological ones). For these wineries, once again, a local supplier is important precept, confirming the relationship

Figure 4. Internal Sources of Information

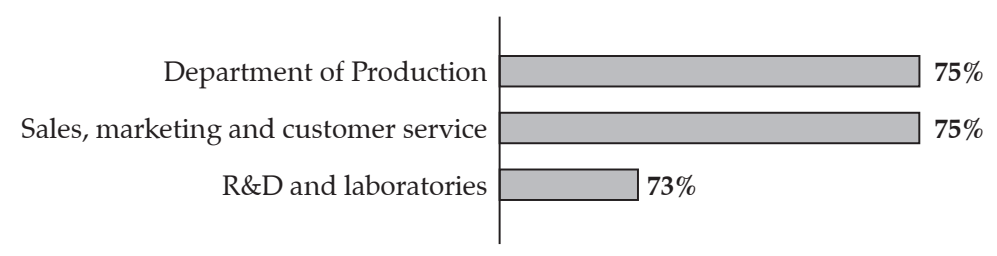

Source: Research data.

Figure 5. External Sources of Information

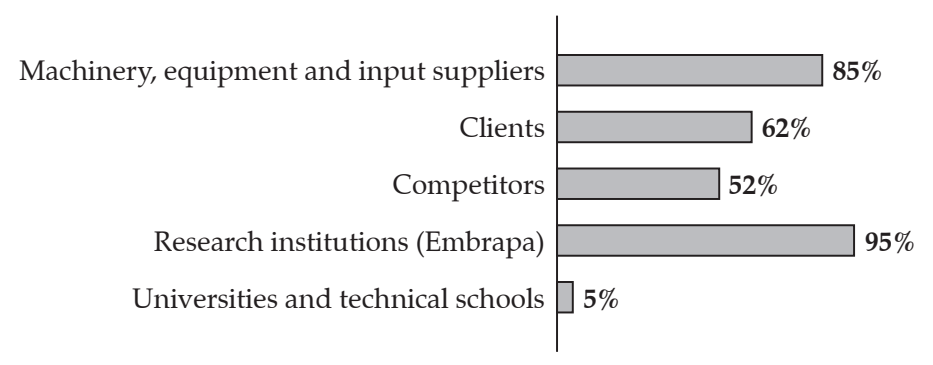

Source: Research data. 
between wineries and their suppliers. This suggests the relevance of geographical proximity and the benefits of face-to-face interaction. As relationships become closer, enhancement paths are established for innovations in the sector.

Clients occupy third place in terms of importance $(62 \%)$ comparing to external sources of information for learning. The clients who receive more attention, unlike suppliers, are those located in other states in the country, especially São Paulo and Rio de Janeiro. The information given to those clients is preferred due to the sales volume and consumption capacity. That reinforces the idea that interactions are not restricted to the cluster, but can also provide with external agents.

Large part of respondents points to a great gap between wineries and their clients, national or foreign ones. Several organizations in the sector corroborate this view, showing the importance of further investments in structuring sales channels, especially in the improvement of relationships with large Brazilian retailers. These channels need qualification and information regarding products, in order to provide more qualified product sales. Logistic questions have been playing an important role in the actions of national companies, especially due to the low competitiveness they have towards the foreign ones in terms of distribution.

A common concern among owners in the Serra Gaúcha's region regards the need to improve their sales and distribution channels. These aspects are essential in order to strengthen the leading role in the internal market. For this reason, enterprises in the sector generally lack competitiveness in terms of distribution logistics. Progress in these issues requires strong investment by the companies, especially in new manufacturing and distribution processes, demanding the internalization of new technological learning.

Competitors constitute the fourth important factor of external sources of information (52\%), especially those located in the cluster. No company interviewed pointed the existence of any formal system to monitor the actions of competitors. That occurs because the actions of companies located in this region are recognized by the social relationships that are set among the firms within the territory.

Other sources of information for the firms studied are conferences, seminars, and courses, held in the Serra Gaúcha's region or abroad, followed by exhibits in fairs and contests. The participation in local business associations and leisure activities in the region were also highlighted. The last two items mentioned show the importance of considering the local systems, once the proximity of agents is also important for the consolidation of a common agenda that involves wineries, grape producers, and institutions as well as the State itself. Giuliani (2013), based on a study within the Colchagua Valley, a wine cluster in Chile, supports this idea. According to the autor, bussiness groups and interpersonal networks are very important. This is due to the fact that "these networks provide access to resources, reduce information asymmetries among firms, enable higher bargaining power vis-a-vis market counterparts, increase lobbying power with governments, and allow firms to upgrade their capabilities" (p. 1417).

The information obtained from the firms allowed for the identification of two learning processes that support the innovation activity of wineries: a) learning-by-doing, which allows for the introduction of new products or new variations of existing products through the analysis of internal information sources (notably information on production and sales); b) learning-by-interacting, which allows for the implementation of productive processes which are better adapted to the needs and characteristics of the wineries, through the analysis of external information sources (especially those coming from the relationship with suppliers). In both cases, innovation was incremental.

The study later attempted to identify the main types of information obtained by companies through the contact with several internal or external sources of information about learning. According to $80 \%$ of the firms, the 
sources provided information on the existence of new products or new grape and wine production processes. For $95 \%$ of the wineries, though, the importance of sources was related to information on possible technological improvements for products as well as processes.

\subsection{Cooperation}

Regarding formal or informal cooperation, companies in the sample were asked whether they had been involved in cooperation. All firms claimed to have developed some cooperative activity during the investigated period.

Afterwards, the study attempted to identify which agents played an important role as partners of these companies. In order of importance, the most important partner for $82 \%$ of the sample are the input suppliers, showing regular exchanges during the period analyzed. Many of these exchanges consisted of the sale of chemical products to vineyards or the supply of biological input necessary to the winemaking process. According to information by many researchers of Embrapa, many of the phytosanitary problems that affect grapevines in the Serra Gaúcha's region can be solved by the intensive use of chemical products.

The use of information sources is once again corroborated by what has been claimed by the firms. This points to the understanding that closer relationship with suppliers is characterized as a deliberate strategy to obtain technological advantages.

Similarly, one can notice that a strong relationship of trust and cooperation between owners and equipment companies in the region has been established. This is due to the fact that many companies develop solutions to specific problems of a certain winery, building a relationship that often goes beyond business.

On the other hand, the presence of multinational equipment and machinery companies (even if they are only represented by Sales offices) shows that national firms have not occupied every space. There are two explanations for this: a) technological gap of national equipment and machinery enterprises in specific segments compared to foreign companies; b) the status granted to the company due to the purchase of foreign equipment. The latter arose during interviews carried out with companies and organizations during this study. Many firms use the import of equipment as a sign of prosperity and success compared to the other forms in the region.

The second partner in order of importance are the representation institutions (75\%); especially IBRAVIN, for the role it has been playing coordinating the main initiatives in the sector.

The third place in order of importance is taken by the support and promotion institutions (SEBRAE, Wines From Brazil12, etc.), accounting for $70 \%$ of the indications by the sample, and the research institution (69\%), especially Embrapa Uva e Vinho. It is important to highlight that the four agents mentioned in the first places of importance in terms of participation in cooperative activities are located inside the wine cluster in the Serra Gaúcha's region. Therefore, although geographical criteria are not usually essential for the development of cooperative activities, it is clear that, in this specific case, territorial proximity allied to agents' social and cultural proximity has played an important role in the consolidation of local innovation, learning and cooperation processes.

Regarding cooperation activities, respondents were asked to point out the main reasons they took into consideration in order to establish a partnership. For almost all, the main criteria used were: trust; partner's reputation (background of relationships with other companies and institutions); partner's qualification and technical knowledge; quality

12. In 2002, IBRAVIN, together with the Agência de Promoção de Exportações e Investimentos (APEX BRASIL), launched the export consortium "Wines from Brazil", with 38 wineries, out of which 34 are located in the cluster. The main objective of the Consortium is to boost the image of Brazilian wine abroad, as well as foster the internationalization of companies in the sector. 
of product or service; proximity between agents; and partner's institutional stability. Only two firms in the sample considered the costs involved in the cooperation activity as significant.

As can be seen in Table 3, the most intensive areas in which the enterprises claimed to have carried out cooperation activities (these activities could take place between companies or between companies and organizations) were sales, export and participation in international fairs and qualification of human resources. This situation is defined by the fact that 13 out of the 20 enterprises participate actively in the "Wines from Brazil" consortium. Accordingly, it is clear that companies that have specific interest in sales and exports were the ones that attracted most cooperation activities.

The areas in which enterprises have the least interest in promoting cooperation activities are: personnel exchange, purchase of technology, R\&D development and tests and certifications and input purchase. As expected, the most sensitive areas, those that show great part of wineries' competitive advantages, are those that receive no cooperation activities, such as personnel exchange, whose intention is to avoid "appropriation of knowledge" that belongs to the company and has been built throughout the years. Such information approaches the results presented by Doloreux and Lord-Tarte (2013), which shows that the forms of collaboration and innovation among wineries in Canada occur at the local level, not considering the interference of the external environment to the business.
Cooperation actions are strongly impaired in areas such as credit, product and packaging design and the joint development of products and processes. Again, it is clear that, in those areas where competition among wineries takes place, there is no cooperation, even if the companies are located within a firm cluster. This means that territories are not spaces that lack competition, but spaces in which cooperative exchanges are promoted.

Respondents were required to assess the results obtained from joint actions carried out in local agents. Results that have the highest importance for wineries were the improvement in product sales $(75 \%)$, followed by improvement in the name/brand promotion in the domestic market (70\%), besides new business opportunities $(65 \%)$ and more participation of the company in international markets (65\%). It is important to highlight that, for many wine companies, the sales of their products in international markets, as well as the presence in fairs and exhibits abroad, promote their products in the domestic market. For this reason, many companies in the sample accept to cooperate in order to access foreign markets, once they attempt, through this cooperative activity, to minimize the risks of exports.

Finally, respondents were asked to point out the main difficulties to develop cooperative actions, especially between firms. Most enterprises do not think it is difficult to find partners $(60 \%)$. For $50 \%$ of them, the problem does not lie in the lack of partners with minimum

Table 3. Areas in which firms established cooperation activities

\begin{tabular}{lccc}
\hline \multirow{2}{*}{ Description } & \multicolumn{2}{c}{ Occurrence } & \multirow{2}{*}{ Total (\%) } \\
\cline { 2 - 3 } & Yes (\%) & No (\%) & 100 \\
\hline Sales & 90 & 10 & 100 \\
Export / Participation in international fairs & 85 & 15 & 100 \\
Training & 65 & 35 & 100 \\
Purchase of inputs & 35 & 65 & 100 \\
R\&D joint & 30 & 70 & 100 \\
Tests and certifications & 25 & 75 & 100 \\
Buying technology & 20 & 80 & 100 \\
Personnel exchanges & 05 & 95 & \\
\hline
\end{tabular}

Source: Research data. 
desired requisites either. However, almost all firms $(95 \%)$ point out that the main obstacle to the development of cooperative activities is the local absence of a cooperation culture, followed by a deep lack of trust among the agents in the region (90\%). Apparently, it might seem that there is a certain contradiction regarding the analysis of the aspects related to cooperation/trust among the agents in the cluster. Nevertheless, what can be perceived is that there is a clear perception about the common points of inflection and, in these cases, there is great internal movement towards cooperation (for instance: in terms of infrastructure, tax issues, requirements for more protection to the local producer, etc.). In the aspects where there is more competition for markets, cooperation actions seem to be weaker, at least among the companies investigated in this study.

\section{Final considerations}

This study aimed to identify and characterize the learning processes that result from strengthening the innovative and cooperative capacity of wineries located in the Serra Gaúcha region. Accordingly, it attempted to contribute for the discussion regarding the role of territorial proximity in the learning, cooperation, and innovation processes of firms in clusters.

The first conclusion is that the wine industry has limited innovative capacity and incremental adaptations of products and processes. This enhancement initiative, despite being reactive, is appropriate when considering the weather difficulties in the northeastern region of Rio Grande do Sul, as well as the strong presence of foreign competitors which, due to production scale and climate advantages of their countries, have a solid competitive position in the domestic market.

The innovations implemented are mainly organizational, promoting market improvement as well as the exploration of new distribution channels and new markets. Such outlook corresponds to the traditional Schumpeterian innovation concept, not linked only to the technological aspect of such processes. According to respondents, innovations should primarily move towards the vineyard, due to gains on product differentiation and permanent competitiveness. However, a great effort would be necessary to link firms and other institutions in the region, thought it has been happening partially due to the former's lack of interest or the communication and relationship flaws. The key to productivity and quality increase lays essentially on investments in research and technological development on the basic input, i.e., grapes.

The vineyard reconversion process still happens slowly because it constitutes a sort of sunk cost. Once replacement takes place, on owner's point of view, the direct consequence is to produce quality wines, and place business on a direct competition with foreign goods. Nowadays there is still a gap in the domestic market for table wines, which requires less technical investment, and that traditionally has a settled niche, operating with appealing margins.

Technological innovations are stimulated by mimetic behavior of observation and adaptation of products to innovations implemented by competitors. This behavior can be perceived in other elements of the production chain, such as national machinery and equipment companies. We can find two distinct technological paths within Rio Grande do Sul's vitiviniculture: one that is based on innovation, through the production of high quality grapes and consequently the production of quality wines and sparkling; and the traditional production of table wines, as well as the recent production of grape juice.

Therefore, innovative processes are perceived as the result of several sources of information, acquisition and diffusion of knowledge among the agents in the territory. Although it is informal and limited, the channels used to acquire knowledge play an important role in enhancing learning, as well as in spreading innovations. When observing the relationship between 
companies and the educational structure, there is a strong bond between them, especially when hiring local technical labor. The firms show that they have been connecting with the IFRS only for hiring interns and students from its colleges, establishing a clear gap in the relationship between that institution and the other actors in the cluster, especially regarding research and extension activities.

Companies have been searching for external information, especially through the participation on international fairs and enology contests, leading to an "overflow" of technical knowledge among such enterprises and positively affecting the quality of products. Therefore, the importance of local actors for the organization and knowledge diffusion systems becomes evident.

The size of companies does affect the search and the type of information sources. Larger companies use information available in several sources, both internal and external. Even not dismissing internal sources of information, in the last years, these wineries have been focusing more on searching for external sources, by hiring international enologists and consultants ${ }^{13}$, setting contracts for the acquisition and maintenance of foreign equipment, as well as forming joint ventures with foreign wineries.

Smaller wineries, on the other hand, access local sources of information more frequently, and one of their ways to renew knowledge is to hire local professionals. The external sources mostly used by these companies are the participation in international fairs and technical visits to foreign companies. Therefore, it is possible to perceive that both larger and smaller wineries access cooperative processes.

Cooperation processes were considered unexceptional, including the existence of vertical and horizontal cooperation. However, relationships between the companies and their

13. Although this practice is only present in one company of Vale dos Vinhedos, due to its importance, it turns out to influence current and future practices of many companies within the Cluster. suppliers are more frequent and valued than cooperation between enterprises themselves.

On the other hand, the main sort of cooperation among companies relies on exportation, due to specific organizational structure and knowledge demand, which does not happen in the small wineries. For this reason, enterprises usually access the consortium Wines from Brazil in order to reach the international market. In any case, one of the reasons that leads different sized firms to the international market are that consumers better evaluate companies that undergo in international wine circuits, through direct export or participation in events.

The representative institutions, especially IBRAVIN, were mentioned due to their important role as partner, articulator and coordinator of actions that supply the needs of the wineries. The structure of this Institution in the last four years has enabled not only wineries, but also some other local actors to increase their trust and grant responsibility for IBRAVIN to be the legitimate representative of the wine segment in Brazil. IBRAVIN incorporates this legitimacy, partly for the relevant political work, countrywide, as well as internationally in order to represent wine producers. Similarly, it is important to highlight that IBRAVIN is the only institution that manages resources from Fundovitis ${ }^{14}$, which has been funding the promotion of domestic wine significantly.

The owner's innovative profile, which is, according to experts, extremely important for implementing successful innovative processes, requires further studies. Another issue that requires deeper analyses is the cooperation processes among companies. The development of empirical studies in this area is essential, not only to enable

14. In 1997, Law number 10,989 was enacted in order to set objectives for the policies and regulation of grape, wine and derivate production, as well as create the Fundo de Desenvolvimento da Vitivinicultura (Fundovitis). This Fund promoted a specific source of resources to be applied to bottlenecks in the sector, such as supervision and planning of the production chain. In July 2007, Law number 12,743 was signed, enabling the direct transfer of $25 \%$ of the funds collected from Fundovitis to Ibravin. 
the expansion of this knowledge, but also because it will necessarily promote interdisciplinary connection among knowledge areas.

\section{References}

ARROW, K. J. The economic implications of learning by doing. Review of Economic Studies, n. 29, 1962, p. 155-73.

BECATTINI, G. The Marshallian industrial district as a socio-economic notion. In: PYKE, F., BECATTINI, G. and SENGENBERGER, W. (Eds.). Industrial districts and inter-firm cooperation in Italy. Geneva: International Institute for Labor Studies, ILO, 1990. p. 37-51.

BESSANT, J. et al. Using supply chains to transfer learning about best practices: a report to the Department of Trade and Industry. CENTRIM, Brighton University, Brighton, 1999.

CASSIOLATO, J. E. and LASTRES, H. M. M. (eds.). Globalização e inovação localizada: experiências de sistemas locais no Mercosul. Brasília, IBICT/IEL, 1999.

CASSIOLATO, J. E. and LASTRES, H. M. M. O foco em arranjos produtivos e inovativos locais de micro e pequenas empresas. In: CASSIOLATO, J. E., LASTRES, H. M. M. and MACIEL, M. L. (Orgs.). Pequena empresa: cooperação e desenvolvimento local. Rio de Janeiro: Relume Dumará: UFRJ, Instituto de Economia, 2003. p. 21-34.

COLEMAN, J. S. Social Capital in the Creation of Human Capital. In LESSER, L. L. Knowledge and Social Capital: Foundations and Applications. New York: The Free Press, 1985. 449p.

COURLET, C. Les systèmes productifs locaux: de la definition au modèle. In: DATAR (Délégation à l'aménagement du territoire et à l'action régionale). Réseaux d'entreprises et territories: regards sur lês systèmes productifs locaux. Paris: La Documentation Française, 2001. p. 17-61.

DODGSON, M. Learning trust and inter-firm technological linkages: some theoretical associations. In: COOMB, R. et al. Technological collaboration: the dinamics of cooperation in industrial innovation. Cheltenham: Edward Elgar, 1996, p. 54-75.

DOLOREUX, D. and LORD-TARTE, E. The organisation of innovation in the wine industry: Open innovation, external sources of knowledge and proximity. European Journal of Innovation Management, Vol. 16, Iss: 2, 2013. p. 171-189.
DOSI, G. Sources, Procedures and Microeconomics Effects of Innovation. Journal of Economic Literature, XXVI, set. 1988.

DOSI, G. Technological Paradigms and Technological Trajectories: a suggested interpretation of determinants and direction of technical change. Research Policy, n. 11, 1982.

FARIAS, C. V. S. and CAMPREGHER, G. A. Incerteza keynesiana, falhas de coordenação e arranjos institucionais: análise da internacionalização da vitivinicultura brasileira através da Wines from Brazil. In: I Forum de Pesquisa em Internacionalização de Empresas, 2008, São Leopoldo/RS. Anais do I Forum de Pesquisa em Internacionalização de Empresas, 2008.

GIULIANI, E. Network dynamics in regional clusters: Evidence from Chile. Research Policy, n. 42, 2013, p. 1406-1419.

IBGE. Pesquisa de Inovação Tecnológica - PINTEC 2008. Rio de Janeiro: IBGE, 2010.

IBRAVIN. Instituto Brasileiro do Vinho. Panorama do Setor Vitivinícola Brasileiro. Disponível em: <www. ibravin.org.br>. Acesso em: jan. 2010.

JOHNSON, B. and LUNDVALL, B. The Learning Economy. Journal of Industry Studies, v. 1, n. 2, p. 23-42, dec. 1994.

LUNDVALL, B. Innovation as an interactive process: from user-production interaction to the national system of innovation. In: DOSI, G. et al. Technical Change and Economic Theory, Pinter Publishers, London, 1988.

LUNDVALL, B-Å and BORRÁS, S. Globalising learning economy: implications for innovation policy. Targeted Socio-Economic Research - TSER, DGXII - European Commission Studies. Luxemburgo: European Communities, 1998.

MALMBERG A. and MASKELL, P. Localized learning revisited. Growth and Change, v. 37, n. 1, 2006, p. 1-18.

MARKUSEN, A. R. Áreas de atração de investimentos em um espaço cambiante: uma tipologia de distritos industriais. Nova Economia, Belo horizonte, v. 5, n. 2, p. 09-44, dez. 1995.

MASKELL, P. and MALMBERG, A. Localised learning and industrial competitiveness. Cambridge Journal of Economics, n. 23, 1999, p. 167-185.

MELLO, L. M. R. de. Vitivinicultura Brasileira: Panorama 2012. Bento Gonçalves: Embrapa Uva e Vinho, 2013. 5 p. (Embrapa Uva e Vinho. Comunicado Técnico, 137). 
NELSON, R. and WINTER, S. An evolutionary theory of economic change. Cambridge: Belknap Press of Harvard University, 1982.

POSSAS, M. L. Competitividade: fatores sistêmicos e política industrial: implicações para o Brasil. In: CASTRO, B., POSSAS, M. L. and PROENÇA, A. Estratégias empresariais na indústria brasileira: discutindo mudanças. São Paulo: Forense Universitária, 1996.

PUTNAM, R. Comunidade e democracia: a experiência da Itália moderna. Rio de Janeiro: FGV, 1996.

ROSENBERG, N. Por dentro da caixa-preta. Campinas/ SP, Ed. Unicamp, 2006.

SCHMITZ, H. Collective efficiency: growth path for small-scale industry. The Journal of Development Studies, v. 31, n. 4, p. 529-566, apr. 1995.
STORPER, M. The resurgence of regional economies, 10 years later. In: STORPER, M. The regional world: territorial development in a global economy. New York, London: The Guilford Press, 1997, p. 3-25.

TATSCH, A. L. Conhecimento, Aprendizagem, Inovação e Proximidade Espacial: o caso do arranjo de máquinas e implementos agrícolas no Rio Grande do Sul. Revista Brasileira de Inovação, Rio de Janeiro (RJ), v. 7, n. 1, p. 63-100, jan./jun. 2008.

VARGAS, M. A. Proximidade territorial, aprendizado e inovação: um estudo sobre a dimensão local dos processos de capacitação inovativa em arranjos e sistemas produtivos no Brasil. Tese (Doutorado em Economia) - Instituto de Economia, Universidade Federal do Rio de Janeiro, Rio de Janeiro, 2002. (digital). 